Article

\title{
Outdoor Education, the Enhancement and Sustainability of Cultural Heritage: Medieval Madrid
}

\author{
María-Luisa Gómez-Ruiz ${ }^{1}$, Francisco-José Morales-Yago ${ }^{2}$ and María-Luisa de Lázaro-Torres ${ }^{2, *}$ (D) \\ 1 Department of Experimental, Social and Mathematical Didactics, Universidad Complutense de \\ Madrid (UCM), 28040 Madrid, Spain; marialuisa.gomez.ruiz@pdi.ucm.es \\ 2 Department of Geography, Universidad Nacional de Educación a Distancia (UNED), 28040 Madrid, Spain; \\ fjmorales@geo.uned.es \\ * Correspondence: mllazaro@geo.uned.es
}

Citation: Gómez-Ruiz, M.-L.; Morales-Yago, F.-J.; de Lázaro-Torres, M.-L. Outdoor Education, the Enhancement and Sustainability of Cultural Heritage: Medieval Madrid. Sustainability 2021, 13, 1106. https:// doi.org/10.3390/su13031106

Academic Editor: Elena Lucchi

Received: 8 January 2021

Accepted: 18 January 2021

Published: 21 January 2021

Publisher's Note: MDPI stays neutral with regard to jurisdictional claims in published maps and institutional affiliations.

Copyright: (c) 2021 by the authors. Licensee MDPI, Basel, Switzerland. This article is an open access article distributed under the terms and conditions of the Creative Commons Attribution (CC BY) license (https:// creativecommons.org/licenses/by/ $4.0 /)$.

\begin{abstract}
Education has a crucial role to play in helping meet the Sustainable Development Goals, for which the initial training of university teachers, and its evaluation, are all essential. In this context, the authors developed an outdoor work task, consisting of an orientation game in 'medieval Madrid'. The main objective was to show future teachers how they can enable their own students to value cultural heritage in order to acquire sustainability competencies. The task was evaluated by participants using a questionnaire, in order to make them aware of the acquired competencies. A gamification component was added to the outdoor task to create a healthy competitive environment. In this way, future teachers were able to observe how a teaching activity is evaluated; learn how to organize a didactic activity that can be extrapolated to other territorial and heritage realities; and employ their mobile devices to learn the foundations of sustainability in heritage management. Additionally, they acquired teaching competencies that promoted quality education and contributed towards two of the Sustainable Development Goals, specifically: 4 "Ensure inclusive and equitable quality education and promote lifelong learning opportunities for all" and 11 "Make cities and human settlements inclusive, safe, resilient and sustainable".
\end{abstract}

Keywords: Sustainable Development Goals; geography; education; outdoor learning; orientation game; heritage; digital competence; training teachers; sustainability competencies

\section{Introduction}

The 2015 United Nations' Sustainable Development Goals (SDGs) declaration included an ambitious program for their achievement by 2030 [1], which is known as the '2030 Agenda'. This Agenda specifies goals and indicators that can be applied in different countries and cities across the world. Consequently, a number of countries have sought to achieve sustainability by adapting SDGs to their reality, such as Poland [2] and Germany [3]. In the latter case, the indicators corresponding to the goals differ, depending on the area in which they apply, whether it be government, academia or civil society. The academic world, and education in general, has a crucial role to play in advancing SDGs by collaborating to achieve them [4]. Thus, teacher training is essential [5,6], as well as direct training of the students themselves [7].

Training teachers in universities can help them to appreciate cultural and natural heritage in their own teaching context, and contributes not only to developing SDG number 4: "Ensure inclusive and equitable quality education and promote lifelong learning opportunities for all", but also works towards SDG number 11: "Make cities and human settlements inclusive, safe, resilient and sustainable", and goal 11.4 "Strengthen efforts to protect and safeguard the world's cultural and natural heritage". To help achieve these objectives, a didactic resource has been built over several years that allows integration of classroom work with an outdoor orientation game within the medieval quarter of Madrid. Specifically, a systematic working method, which includes analysis and assessment, has 
been developed jointly with students on the Master in Teacher Training at Madrid's Complutense University (UCM), within the specialty of Geography and History, allowing them to work on these SDGs by actually implementing them.

On the one hand, this system has enabled students to create and recreate didactic activities using an active methodology that encourages them to reflect on real-life problems in current urban environments [8,9], where most of them live, even though specific characteristics may differ depending on the specific global region. On the other, there are also similarities in urban environments and in the novelty of some of these problems, as the result of the evolution of a globalized society. Thus, it can be seen that many European cities have moved from deterioration and abandonment to 'saturation by tourism', with the consequent conversion of these environments into "historical" and "artistic" places, which are very far removed from the experience of the city's own residents.

Spain is a leading country in scientific production on heritage education [10-13], and the State and the Autonomous Communities coordinate a National Plan for Education and Heritage Organizations. The Observatory of Heritage Education in Spain (OEPE) is another interesting initiative [14], and the education system itself has included this issue in successive approved curricula: LOGSE (1992), LOCE (2000), LOE (2007) and LOMCE (2014). Thus, education plays a key role in citizens' cultural values [15,16]. This theme is also very present in the Council of Europe [17], and has been developed in four lines of research [18]: the communication of heritage; the teaching of heritage; heritage education and curricular aspects related to heritage; and teacher training, which are also included in several of the SDG targets. However, while a growing number of teachers have been specifically involved in different aspects of sustainability, the entire teaching community is not involved, and nor do teachers have the same degree of commitment. Activities aimed at sustainability education have been designed and carried out at different levels (personal, group and intergroup; and within one or more disciplines), which have given rise to collaboration on different spatial scales (global, national, regional and local). The aim has been to make teachers aware that a small change in approach can enhance the curriculum and plant a seed of collaboration for the achievement of the SDGs.

Additionally, there is a teaching tradition in organizing learning activities outside the classroom (fieldwork) across very different disciplines (psychology, engineering, art, geography, etc.), especially if the subject is related to: the natural environment or landscape $[19,20]$; the environment or architecture [21-24]; use of didactic itineraries [25-35]; visits to museums [10,36-39]; orientation games [40,41]; and the use of mobile devices [42-49].

For a better knowledge of the cities necessary to fulfil "Make cities and human settlements inclusive, safe, resilient and sustainable" (SDG 11), methods and activities need to be adapted to help achieve the specific goal 11.4: "Strengthen efforts to protect and safeguard the world's cultural and natural heritage" work should be undertaken towards these objectives:

(a) From the scientific culture perspective, to favor the approach of valuing heritage, the orientation game helps crystallize knowledge of the territory and the heritage of the place where the method is applied and developed. The aim is that the student appreciates the value of the fieldwork data, which facilitates their understanding of that space. In this process, both digital and spatial skills are improved, since coordinates are understood and managed in a practical way.

(b) From the quality of the teaching-learning perspective, to apply the knowledge acquired in class by linking the classroom or laboratory experience with the real life geographic and historic center of Madrid. Significantly, this is experiential learning in which students interact with each other, and learn in a fun way.

(c) From the socio-emotional perspective, to promote gender equality through groupwork and via the management of technology. The students, without distinction of sex, will experience moving freely and safely through the oldest part of Madrid, learn about its cultural heritage and the evolution of its civilization, thereby fostering responsible citizen awareness in relation to the value and conservation of the past. 
The aim is to show future teachers that it is possible to integrate SDGs within the current curriculum, in a natural way, through the design and organization of activities, in this case, outside the educational center with an orientation game.

Having provided the rationale behind this study, this paper now details the methodology, participant profiles, the space in which the action is carried out, the design and organization of the orientation game and how it was analyzed and assessed. The results are then followed by the conclusions and recommendations.

\section{Methodology}

Quantitative and qualitative data was collected via a questionnaire delivered to students in teacher training. This enabled identification of the strengths and limitations of the activity, which promotes the valuation of heritage and reinforces quality education. Although this working method began prior to the SDGs, the analysis carried out during its evolution and implementation meant that it converged towards two of them: that related to cities-SDG 11 (and its target 11.4) — and that related to the quality of education-SDG 4 (and its target 4.7 ). With this double perspective, the activity was developed in the following way:

1. Selecting participants, who are students undertaking a Master's degree in 'Teacher

Training for Secondary Education and Baccalaureate in Geography and History' at Complutense University of Madrid.

2. Studying 'medieval Madrid', as it seemed appropriate to carry out the activity in the same city as the university.

3. Explaining the orientation game to participants.

4. $\quad$ Preparing the necessary materials.

5. Delivering a questionnaire to participants after the outdoor task. This activity enables student learning to be assessed, and to identify the skills or competences achieved.

In Spain, those who want to become secondary school teachers must do a Master's in Secondary Education, following their university degree. Thus, these future teachers are university students again while they are studying this specific Master.

The orientation game (outdoor learning) was developed over three different academic years (2015-2016 to 2018-2019), allowing improvements to be made annually, based on the results of the questionnaire. For example, in the first year, the task was compulsory, but it was made voluntary in subsequent years. One of the reasons for this was that the only time to do it was on a Saturday, and some students were not able to attend on a 'no lesson day'. This explains the decrease in the number of participants. Table 1 shows the total number of participants $(n=108)$, by year. More men $(56.5 \%)$ than women $(43.5 \%)$ participated, which is in line with the percentage of UCM Master registered students.

Table 1. Student participation.

\begin{tabular}{cccc}
\hline Year & Men & Women & Total \\
\hline 2014 & 28 & 24 & 52 \\
2016 & 17 & 13 & 30 \\
2018 & 16 & 10 & 26 \\
Total & 61 & 47 & 108 \\
\hline
\end{tabular}

Source: own work based on the questionnaires.

Madrid's historic center was chosen, which corresponds largely to the "Morería" (Arab) and the Jewish quarter, two of its three original neighborhoods. This was selected because of its proximity to the University Complutense of Madrid; the geographical diversity of the students; and the concentration of monuments and other original elements of the urban fabric (as it not only collects physical elements, but also traditions, legends and other aspects of intangible heritage). Additionally, it is a quiet area with little traffic, which makes it ideal for undertaking this type of activity. 


\subsection{The Orientation Game Design Explained}

The orientation game has four parts:

1. Prior to the activity, student motivation and previous knowledge is identified in lectures;

2. Key information about the places to visit is gathered and processed (see point 2.1.2) and team groups are organized;

3. Fieldwork is undertaken;

4. The knowledge acquired after fieldwork is reviewed.

2.1.1. Before Starting the Activity Design: Motivation and Identification of Previous Knowledge

The identification of previous knowledge is an essential element in all learning, not only so that students build their own knowledge base [50-52], but also to encourage openness and enthusiasm to learn $[21,53,54]$. In this case, participants are asked to recall and share motivational experiences that they had had in their own learning. A total of $80 \%$ of the students stated that they had never done this type of motivation-related activity before, and only $20 \%$ of students had undertaken study tasks outside the classroom, of which only $5 \%$ could identify a 'playful component'. Consequently, the future secondary school teachers were made aware that play is an essential element in motivation, and they were invited to apply this perspective to gain knowledge about the city's heritage.

\subsubsection{Preparation of the Orientation Game: Collecting and Processing Information}

Before starting the orientation game, in order to take full advantage of it, students need to know exactly what the activity consist of and what kind of information they need. Thus, some theoretical content is provided in lectures.

This content is focused in three directions:

1. From a substantive perspective, students work on the city, its historical evolution and the structure that emerges from it, thereby learning about its urban heritage and value. Simultaneously, students are encouraged to apply their heritage learning to other cities that they themselves know.

2. From an operational point of view, students learn the techniques necessary to acquire cartographic knowledge, understand a map and orient themselves with it, as well as learn the fundamentals of some global navigation satellite systems available on mobile devices, such as GPS, Galileo and Glonass.

3. From a formal perspective, students work on organizing the orientation game in the environment in which it takes place. The future teachers have to establish how the teams should be composed; identify the basic rules of coexistence; establish the rules of the game; and manage their time and 'space control' - while always taking into account the educational level of those being taught.

\subsubsection{Orientation Game: Fieldwork}

The students, organized into groups of two or three, are asked to: locate, on a blank map (Appendix A), corresponding to a reduced area defined for the work, six artistic and cultural heritage "treasures", both tangible and intangible; provide the coordinates of their location; respond to a series of questions on a worksheet given to each team (Appendix B); offer evidence of the importance of the cultural item; and take a photograph or selfie as proof that they had visited that place. In order to complete this task, they were previously asked to carry at least one pen and their own smartphone.

The total duration of the game is one hour. It starts in the Plaza del Granado (or Granado square; indicated as " $\mathrm{S}$ " on the map provided, Appendix A) and begins with a starting signal (e.g., with a whistle). The teams then orient themselves using the map, connect their GPS and organize an itinerary that allows them to cover the route efficiently and effectively. 
The game ends in Puerta Cerrada, which means Closed Door (indicated as "Ll" on the map provided, Appendix A), within a maximum and minimum time, so as not to be disqualified, and deliver the answers to the questions (detailed in Appendix B). The organizers then assess the completed work by considering the margin of error of the coordinates (depending on the devices used), looking at the images on their own smartphones and checking the responses to the questions. In any case, to speed up the review, it is helpful to have more than one teacher, so as to reduce the delay before the awards ceremony. The group that most quickly and accurately performs the activity are declared the winners. In our case, all the students finished the activity within the scheduled time, with great satisfaction, not only at the moment of finishing the activity, but also in the responses to the questionnaire itself.

\subsubsection{The Knowledge Attained after the Fieldwork}

The activity must be understood in a similar way to a laboratory experience, which allows the exploitation, evaluation and/or review of work undertaken outside the classroom, so that students can exchange and share their experience, their discoveries and its meaning among their peers. In this way, students review the knowledge acquired, while also using new technological tools, for example, via the images offered by the National Plan for Aerial Orthophotography (PNOA) available in the Iberpix, CartoCiudad or SignA viewers, created by the Spanish National Geographic Institute. These tools offer the most curious students the largest amount of open data or geodata available in Spain.

\subsection{Preparation of the Necessary Materials for Development of the Game}

The materials include at least a map and a worksheet (Appendices A and B), which are provided at the beginning of the outdoor activity. Teachers give an explanation of the principles on which the global navigation satellite systems is based (GNSS), and ask students to download an application for use on a personal or computer mobile device (for example, the "Mapas de España" App, provided [55] by the Spanish National Geographic Institute). A Garmin Dakota30 GPS terminal is also offered to those students who voluntarily want to use it, instead of the smartphone GPS.

The last session, before carrying out the activity, is used to explain to students about the importance of fieldwork as an ideal system for alternative learning outside the classroom, the importance of personal responsibility and respect for the previously established norms of behavior. This should avoid discipline problems and ensure that respect is shown for fellow citizens.

\subsection{Design of a Questionnaire to Demonstrate the Learning of Future Teachers, Who Are Currently Students}

Evaluating experience is an essential element in teacher training, to make students aware of the learning acquired. For this purpose, different techniques can be used, such as "brainstorming" or answering questions with Kahoot-type tools, which facilitate reflection and analysis of the applied innovation elements.

In this case, a conventional questionnaire is used. In the first observation undertaken (2014-2015 academic year), students responded to the questionnaire at the time of the final exam. In 2016-2017, the same questionnaire was delivered, but using Google Forms, as it has many advantages (such as easy correction), especially if a computer room is available. In the third observation (during the 2018-2019 academic year) replying to the questionnaire was voluntary, again using a link in Google Forms. In all three cases, the questionnaire makes it possible to collect quantitative and qualitative data with a dual purpose: to make students aware of what they have learned and to assess the usefulness of the 'outlearning' experience. Specifically, the questionnaire focuses on three areas: (a) learning achieved (without expressly asking about patrimonial elements); (b) technologies used and; (c) the didactic utility of the activity. In addition, gender data is collected. The questionnaire asks:

(a) In relation to what has been learned and the orientation game itself: 
- Have I learned anything from the activity? If so, briefly state what has been learned.

- Have you completed the activity?

- Have you raised any questions about the activity on the Virtual Campus?

(b) In relation to applied technological skills:

- Has your workgroup employed mobile devices? If so, what did you use them for?

- Did you already know how to use mobile devices for this type of activity?

(c) In relation to the usefulness of the experience:

- Do you consider that the activity has a didactic utility? Why?

- Would you use it in other places? Where?

- Could it be used to acquire new knowledge? What, specifically?

(d) Suggestions for improvement:

- Could the approach to the activity be improved?

- Give examples of the aspects that could be improved.

\section{Results}

During the three years in which the activity was monitored, all the students stated, after performing the orientation game, that they had learned something, with the exception of three subjects, all males, who claimed not to have acquired any knowledge at all-although, curiously, all three gave examples of acquired learning and two of them considered the activity to be didactic. Additionally, one of them claimed that he had not completed the activity, which was the case with four other people (two in 2016 and two in 2018).

The experience and evaluations collected during the first year of the activity allowed us to make adjustments in subsequent years, on the basis of the students' own feedback. Thus, for example, among the aspects that were indicated as 'improvable' was that the group was too large (more than $90 \%$ of the Master's students participated in this experience), and it was suggested that it should be a voluntary activity. This modification was introduced so that attendance was 50\% in the second academic year of observation (2016-2017) and around $40 \%$ in the third (2018-2019). It should also be noted that students completed the feedback questionnaire at home voluntarily.

\subsection{Quantitative Assessment of the Orientation Game}

The degree of satisfaction and student learning is reflected in the fact that the majority respond positively to the questions requested (Table 2), except in relation to the Virtual Campus, which is a space that not all students use, except when it is specifically required. Students predominantly consult documents uploaded to the Virtual Campus by the teaching staff, which represents a challenge for better integration of these campuses in teaching. However, although the numbers are low, there have been a growing number of consultations each year. The dissatisfaction of the students in the first year of the experience, regarding the high number of participants, is reflected in the high percentage of subjects who indicated that 'there is something that could be improved'.

Table 2. Percentage of students who agreed with the following statements.

\begin{tabular}{cccccccc}
\hline Statements Regarding ... & \multicolumn{3}{c}{ Men (\%) } & \multicolumn{2}{c}{ Women (\%) } & Total (\%) \\
\hline What was Learned and the Activity Itself & $\mathbf{2 0 1 4}$ & $\mathbf{2 0 1 6}$ & $\mathbf{2 0 1 8}$ & $\mathbf{2 0 1 4}$ & $\mathbf{2 0 1 6}$ & $\mathbf{2 0 1 8}$ & $\mathbf{2 0 1 4 - 2 0 1 8}$ \\
\hline I have learned with this activity & 96.43 & 88.24 & 100.00 & 100.00 & 100.00 & 100.00 \\
I have done the full activity & 100.00 & 82.35 & 87.50 & 100.00 & 100.00 & 100.00 & 97.22 \\
I have raised it on the Virtual Campus & 42.86 & 64.71 & 87.50 & 45.83 & 30.77 & 100.00 & 57.41 \\
\hline
\end{tabular}


Table 2. Cont

\begin{tabular}{cccccccc}
\hline Statements Regarding ... & \multicolumn{3}{c}{ Men (\%) } & & Women (\%) & Total (\%) \\
\hline Applied Technology Skills & & & & & & \\
\hline Mobile devices have been employed & 96.43 & 88.24 & 100.00 & 100.00 & 100.00 & 100.00 \\
I know how these activities are handled & 92.86 & 88.24 & 87.50 & 79.17 & 92.31 & 100.00 & 87.22 \\
\hline Educational Utility of the Activity & & & & & & & \\
\hline I consider the activity didactic & 92.86 & 100.00 & 100.00 & 95.83 & 100.00 & 100.00 & 97.22 \\
I would extrapolate it to other areas & 85.71 & 94.12 & 93.75 & 95.83 & 76.92 & 90.00 \\
I would use it to learn other things & 85.71 & 76.47 & 93.75 & 91.67 & 92.31 & 100.00 & 89.81 \\
There is something that could be improved & 75.00 & 47.06 & 25.00 & 54.17 & 23.08 & 40.00 & 52.78 \\
\hline
\end{tabular}

Source: own work based on the students' questionnaire.

\subsection{Qualitative Assessment of the Orientation Game}

The specific answers to each of the qualitative questions are set out below, starting with one that responds to what they have learned and comparing it with the potential of the activity for learning (what can be learned) if you apply it to other places; that is, the power of the method. The responses have been organized focusing, on the one hand, on what has been learned in relation to the valuation of heritage (goal 11.4), and, on the other, on the teaching competencies developed through the activity (spatial, digital and teaching quality skills, such as the method that can be followed to organize an activity of this type and promote cooperative and collaborative work).

\subsubsection{Feedback on the Learning Achieved by Future Teachers}

Students feedback included:

- "II have learned] to merge daily geographical and historical contents of the immediate surroundings, with an itinerary (field trip) and through collaboration to make it meaningful"

- "II have become more] efficient carrying out an activity in a small part of Madrid, with an entertaining, didactic and physical activity ... very interesting"

- " "II was] able to orient myself around Madrid, get to know the historic center of 'Los Austrias' and work as a team to understand its cultural and historical significance"

- "I've only been in Madrid for a year and this game has helped me to see places that, on my own, I would not have visited, such as the Jewish quarter"

- "I have learned how to participate in a good educational game [and ... ] develop my skills as a teacher"

- "[I have gained a] new teaching resource to work with students"

- "I have rediscovered the space and the historical monuments, the urban fabric, the origin of the street names, the location of the city walls and their changes..."

Based on the tabulation of the responses collected (Table 3), we can highlight the following reflections in relation to what has been learned and the power of the technique to learn about the two areas of work related to SDGs: heritage (goal 11.4) and skills or competencies for teachers (target 4.7). 
Table 3. Percentage of students who have learned, and the power of the technique to learn.

\begin{tabular}{|c|c|c|c|c|c|c|c|c|c|}
\hline \multirow[b]{2}{*}{ Heritage } & \multicolumn{4}{|c|}{ I Have Learned } & \multicolumn{4}{|c|}{ It Can be Learned } & \multirow{2}{*}{$\begin{array}{c}\text { Total (\%) } \\
\text { Difference }\end{array}$} \\
\hline & 2014 & 2016 & 2018 & Total & 2014 & 2016 & 2018 & Total & \\
\hline About the city of Madrid and its past & 46.15 & 56.67 & 46.15 & 49.07 & 7.69 & 0.00 & 7.69 & 5.56 & 43.52 \\
\hline Integrate valuation of heritage and fun & 7.69 & 10.00 & 7.69 & 8.33 & 0.00 & 0.00 & 0.00 & 0.00 & 8.33 \\
\hline $\begin{array}{l}\text { Unique buildings, museums and } \\
\text { monuments }\end{array}$ & 3.85 & 0.00 & 3.85 & 2.78 & 9.62 & 3.33 & 3.85 & 6.48 & -3.70 \\
\hline $\begin{array}{l}\text { Heritage content of Social Sciences (art, } \\
\text { history, geography), literature, } \\
\text { anthropology, music, ecology. }\end{array}$ & 0.00 & 0.00 & 0.00 & 0.00 & 75.00 & 20.00 & 26.92 & 48.15 & -48.15 \\
\hline $\begin{array}{l}\text { Natural heritage (flora, fauna, } \\
\text { geology...) }\end{array}$ & 0.00 & 0.00 & 0.00 & 0.00 & 5.77 & 6.67 & 0.00 & 4.63 & -4.63 \\
\hline \multicolumn{10}{|l|}{ Teaching Competencies } \\
\hline Organize a didactic activity & 28.85 & 30.00 & 57.69 & 36.11 & 0.00 & 0.00 & 0.00 & 0.00 & 36.11 \\
\hline Orientation (spatial competence) & 15.38 & 26.67 & 3.85 & 15.74 & 9.62 & 16.67 & 7.69 & 11.11 & 4.63 \\
\hline Cartography management & 15.38 & 3.33 & 11.54 & 11.11 & 9.62 & 0.00 & 0.00 & 4.63 & 6.48 \\
\hline Manage coordinates to locate a place & 15.38 & 10.00 & 11.54 & 12.96 & 1.92 & 3.33 & 3.85 & 2.78 & 10.19 \\
\hline Teaching app for mobile devices & 7.69 & 0.00 & 0.00 & 3.70 & 1.92 & 0.00 & 0.00 & 0.93 & 2.78 \\
\hline GPS & 11.54 & 0.00 & 0.00 & 5.56 & 0.00 & 3.33 & 0.00 & 0.93 & 4.63 \\
\hline Google Maps & 0.00 & 10.00 & 0.00 & 2.78 & 0.00 & 0.00 & 0.00 & 0.00 & 2.78 \\
\hline Collaborative competition & 9.62 & 3.33 & 3.85 & 6.48 & 1.92 & 3.33 & 7.69 & 3.70 & 2.78 \\
\hline Export and transfer the activity & 5.77 & 0.00 & 0.00 & 2.78 & 0.00 & 0.00 & 0.00 & 0.00 & 2.78 \\
\hline \multicolumn{10}{|l|}{ Other Contents } \\
\hline Observe the environment & 0.00 & 0.00 & 0.00 & 0.00 & 9.62 & 3.33 & 7.69 & 7.41 & -7.41 \\
\hline Town planning & 0.00 & 0.00 & 0.00 & 0.00 & 21.15 & 3.33 & 15.38 & 14.81 & -14.81 \\
\hline Detected contamination & 0.00 & 0.00 & 0.00 & 0.00 & 1.92 & 0.00 & 7.69 & 2.78 & -2.78 \\
\hline $\begin{array}{c}\text { Others (economy, tourism, science, } \\
\text { mythology, mountain activities, } \\
\text { health...) }\end{array}$ & 0.00 & 0.00 & 0.00 & 0.00 & 5.77 & 0.00 & 11.54 & 5.56 & -5.56 \\
\hline
\end{tabular}

Own work based on the students' questionnaire. The negative sign shows the potential of the task for learning in other context, that is, what can learn with this method, and its usefulness when the context is changed.

\section{(a) Heritage valuation}

All students agree that they have acquired greater knowledge about Madrid and its history. The activity shows the students' a new perspective of the city with elements and places that until now were unknown to them, such as the Casa del Pastor (the house of the shepherd) and the old house of Iván de Vargas, currently converted into a museum. This feedback was received by both students who reside in the city and those who do not. Half of the students agreed that the activity allowed them to better understand the history of Madrid. Some add specific details related to cultural and architectural elements (such as art, anecdotes, medieval past, corners, building materials, etc.) and geographical (urban fabric, reuse of space, land use, gentrification etc.). However, many nuances remain open about the potential of the activity, which are collected in Table 3.

(b) Assessment of the teaching skills acquired

Students learned: to organize a didactic and fun activity that is valued positively, by taking advantage of various spatial and digital aspects, with mobile devices and maps (some students speak more generally about maps); the importance of the combination of variables for the selection of an ideal place for the realization of a game of this nature with schoolchildren (such as selection of the area of action, a place that is historically significant, but that does not have much traffic or much influx of people so that students can move freely and safely); the possibility of applying the theory and practice seen in lectures and learning to structure a didactic resource with spatial, temporal and academic coherence; and the group competences acquired, with an interaction within the group that has facilitated peer learning, discovery learning. 
The greatest criticism received, in terms of the organization of the activity, was that made by the first observation group (2014), who were concerned that it was very close to the exams, and, furthermore, that it was a compulsory activity.

\subsubsection{The Use of Mobile Devices}

The use of mobile devices applied to teaching-beyond their use as GPS or to find the coordinates, (e.g., to look for information and find the right angle to photograph the "treasure"), was valued very positively. In the 2014 observation, students stated that they had used them in a natural way to: find the coordinates of "treasures" or heritage sites; locate streets and sites; help in orientation (Google Maps); take a photograph of the place (selfies); obtain additional information about the place; and be able to respond more easily to the questions (using Wikipedia and Webpages about Madrid). In the observation of 2014 (Table 4) it can be seen that students only cited uses that had most attracted their attention, for their novelty, such as the search for coordinates.

Table 4. The use of mobile devices in students' outdoor activities.

\begin{tabular}{ccc}
\hline Use of Mobile Devices & No. of Cases & Total (\%) \\
\hline Information search (Wikipedia, Google Maps, Google Earth) & 10 & 19.23 \\
Take photos (selfie) & 5 & 9.62 \\
Find coordinates & 39 & 75.00 \\
GPS & 9 & 17.31 \\
\hline
\end{tabular}

Source: own work based on students' 2014 questionnaire.

In order to avoid exceptionality in the following observations (years 2016 and 2018), it was decided to change the way to formulate this question by using a closed question, with the following multiple-choice options: "obtain information about the monuments using an Internet connection", "take photos", "look for coordinates" using a GPS device and other options. The others option only had two new features: "the use of mobile phones for emergencies", and the "possibility that mobile devices offer to organize and distribute or divide the work" (Figure 1).

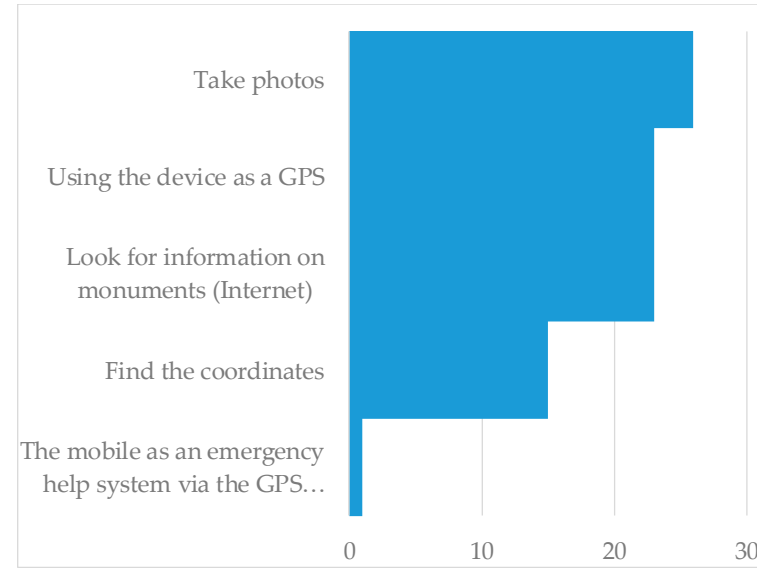

(a)

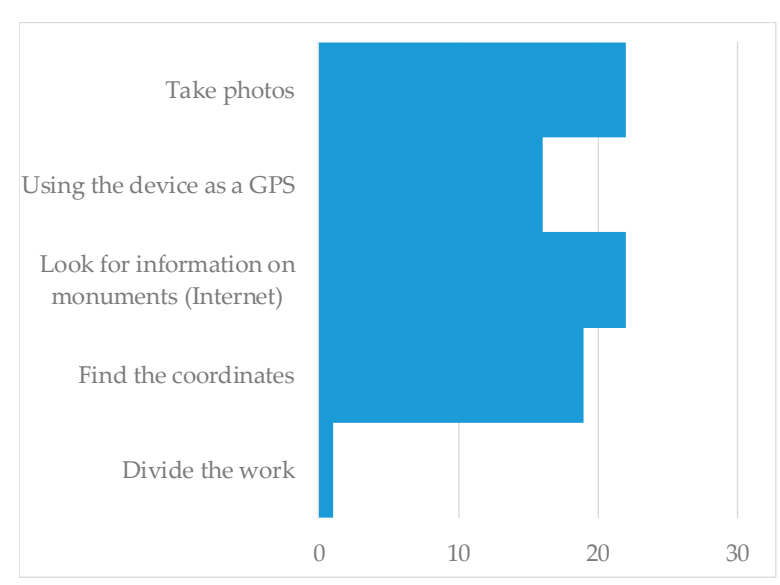

(b)

Figure 1. The use of mobile devices in student outdoor activities in two different academic years: (a) $2016-2017$ ( $n=30)$ and (b) 2018-2019 ( $\mathrm{n}=26)$. Source: own work based on the students' questionnaire.

\subsubsection{The Didactic Nature of the Activity as Seen by Future Teachers}

All except one student have affirmed that the activity is didactic, and that they have acquired spatial skills such as: learning to locate oneself in the city; being able to follow their movements through it; and learning to interpret a map. They have also managed to apply the geographical content acquired in class and have oriented their digital skills in 
the use of technology (mobile devices and GPS) in a contextualized way and applied it to learning.

In relation to patrimonial aspects, they affirm that they have established historical, artistic and patrimonial knowledge. They have learned to value the nearby environment and have discovered elements that can be thought of as 'the city's memory', that they were unaware of.

In relation to the didactic aspects, experiential and discovery learning is worked on explicitly, but also to acquire cooperative and group skills, such as peer help, and promote teamwork. Students consider the experience to be a different way of learning, which is innovative and motivating. It also requires students to overcome difficulties and stimulates the search for answers, and allows the application of mobile devices, so widely used in daily activities, to solve spatial and academic problems. It is, therefore, a useful and practical activity, in which you learn in an enjoyable and fun way. Additionally, students can use the game to teach in secondary schools. Others, furthermore, see potential for interdisciplinarity and transdisciplinarity, which is an essential element for solving problems and addressing sustainability in the way defended by many authors [56,57].

It is worth highlighting some of the student feedback:

- "With mobile devices we have discovered heritage elements in a fun and experiential way that is hard to forget".

- "It is an experiential practice that integrates theory and practice. We learn in an enjoyable way, which encourages self-discovery and the appreciation of a close environment".

- By turning the activity into a challenge, "it encourages participants to put in effort. Besides, they are given autonomy and movement, something that completely breaks with the scheme of a theoretical lesson in a classroom".

- "We have had fun while we have learned and have developed the group by doing the activity together".

- "We not only use mobile devices and applications in a different way, but we also have learned how to behave and how to organize a group for a didactic fieldwork".

- "It mixes resources, unites groups and is fun; and at the same time, it allows us to put into practice the contents studied in class".

Additionally, students felt that these types of activities help to solve problems outside the classroom and allowed them to see how didactic fieldwork can be carried out in a rigorous and entertaining way.

\subsubsection{The Possibilities to Disseminate the Activity to Other Settings}

Most participants are drawn from the degree in History and History of Art and many of them consider the activity to be applicable and useful in their own discipline. A quarter also suggest applying it to literature, culture, music, sciences and urban aspects (such as rehabilitation, land use, delimitation of the historic center and potential expansion). Social aspects, such as immigration and gentrification, have also been suggested.

In relation to geography, participants consider the activity suitable for other pedestrian spaces, and any environment in which the educational center is located, be it urban or rural. It could easily be applied to other areas and neighborhoods of Madrid, other municipalities in its province and other urban spaces (Table 5). Rural and natural spaces may also be potentially suitable (such as La Sierra de Madrid, La Pedriza, La Sierra de Guadarrama, Los Parques Nacionales, Navacerrada, El Pardo, etc.).

In fact, this learning method can be employed in any space known to the teacher, even in a museum, although it is suggested that it should always be a relatively quiet place without much traffic. Other potential cities are provided below, since the population in Spain is mostly urban. Madrid stands out over other geographical areas but over $25 \%$ of students suggested applying the activity to the heritage city of Toledo. 
Table 5. Urban spaces in which students would apply the resource or activity.

\begin{tabular}{ccc}
\hline $\begin{array}{c}\text { Other Madrid Districts and } \\
\text { Neigbourhood }\end{array}$ & $\begin{array}{c}\text { Madrid Province } \\
\text { Municipalities }\end{array}$ & Other Cities and Towns \\
\hline Atocha & Alcalá de Henares & Aranjuez \\
Arganzuela & Boadilla del Monte & Ávila \\
Barrio de las Letras & El Escorial & Barcelona \\
Castellana & Getafe & La Granja (Palacio de) \\
Chambería & Móstoles & Granada \\
Chueca y Malasaña & Navalcarnero & Plasencia \\
Ensanche barrio Salamanca & & Salamanca \\
Ensanche Argüelles & & Segovia \\
La Latina or Lavapiés & Seville \\
Plaza Mayor & Sigüenza \\
Calle de Alcalá and Gran Vía & Toledo \\
El Madrid de los Austrias & & \\
Palacio de Oriente & \\
Paseo del Prado & & \\
Triángulo del Arte & & \\
Vallecas & & \\
\hline Source: own work based on student questionnaire. &
\end{tabular}

It is clear that the activity can be employed in other places, circumstances or in other subjects, although most of the areas mentioned above have a patrimonial and emblematic value.

Finally, it is notable that all the students responded with some contribution to this question, except for three who left it unanswered.

\subsection{Improvable Aspects of the Activity}

As pointed out above, although the activity clearly aids efficient learning, improvements were made in its organization and design in 2014, to make it both optional and reduce the number of participants. However, there were students who considered the activity to be very well planned, which boosted motivation. The award ceremony and the feedback activity at the time of its completion were particularly positively valued, although there was also a debate about the most appropriate way to deliver the awards (e.g., whether to only reward the best, or to congratulate everyone for their participation).

Some students suggested more explanation about: GPS; the artistic-cultural heritage; and the location of the "treasures". However, the activity has been repeated with groups of high school students on several occasions since, and they have not encountered any difficulties in these aspects. Other suggestions included more student interaction with the neighborhood's inhabitants, and the shops and/or markets. History of Art students asked for more information about architectural styles and to be allowed to enter the monuments.

The observation exercise in 2016, in which students could choose the activity, offered very positive feedback, despite the inconvenience of the threat of rain. In this regard, some participants suggested that it is an activity that can be easily postponed to a day with favorable weather conditions. However, experience shows that this is not the case, as it is often difficult to find other spaces in the timetable. Furthermore, this activity has also been carried out with high school students and has always been a success, regardless of the weather situation, with high levels of motivation observed.

Other participants suggested completing the game with a second individual section, in a different area, but experience has shown us that the total estimated time of two hours: one with the task, and another divided between the initial explanation in situ and delivery of material and the final correction after the task is sufficient for such an intense activity.

In the third observation (2018), some students indicated that the time left for the activity was very short, and that as it was competitive it forced them to go faster than they wanted. Other participants suggested that there be consolation prizes for all participants, even if they did not win. Some also made a technical observation: when using Google 
Maps, the point to be located is marked and the coordinates appear, so that a specific GPS program is not necessary (what is important is to search for their exact location on the map provided). They also found the questionnaire correction "in situ" slow, which is why we suggested that with the help of another teacher, it could be faster. Another suggestion was to reduce the number of questions to answer. Finally, many students found it very complicated to use the blank map that was given to them, because, although the delimited area is small, they are not accustomed to use such concise cartographic information. Additionally, it must be borne in mind that most participants, are future Social Sciences teachers, and come from specialties other than geography, and are not used to working in cartography, or to comparing maps with the physical reality.

\section{Discussion}

From the large number of suggestions and ideas detailed above, it is clear that the activity was, in general, very positively received by students. In fact, participation in the didactic experience was greater than that shown in the statistical data, as only the results of those who completed the surveys are presented here. The purpose of the orientation game was not to give a numerical mark to the student/future teacher for their work, but for them to acquire applied teaching skills. The satisfactory results and subsequent analysis again demonstrate the effectiveness of this learning method, as has been found in other topics, such as learning English language [58]. The activity has introduced tools that assist future teachers in designing outdoor learning activities that enhance satisfaction as well as learning from on-site work [59].

However, it does have the limitation that many teachers believe that outdoor activities or fieldwork can involve risk [60]. In order to address this issue, the target of this activity is upper secondary school students who are at least 14 years old, as this is the age at which Spanish students begin to go to school alone and go out without their parents, and when they are considered sufficiently developed and autonomous.

Outdoor activities and fieldwork are considered 'good practice' if they are carefully planned [61,62]. As is well-known, experienced teachers and youth leaders work very well with these kinds of activities as key elements, for example, in geography education. Furthermore, experiential learning [63] is not only important for secondary students, but also for training teachers. Therefore, the experience seeks to demonstrate that it is possible to organize and carry out this activity, which both improve academic achievement and student social/emotional intelligence [64]. Some studies have focused on heritage [59,65], even as a game [66]; however, very few universities do heritage learning in a formal teacher-training context, as has been done in this research.

By participating in the didactic activity, future teachers have acquired competencies in an experiential way, outside the classroom, in their urban surroundings which is where 'heritage is located', thus being able to have direct contact with it. Additionally, they have been able to see and experience for themselves the pros and cons of organizing these types of activities, which is also useful for in-service teachers [67]. A number of them, who are now practicing teachers, have employed an adapted version of this orientation game with their own high school students which can be also be replicated using Appendix C.

One area of improvement might be in 'the weight' given to SDGs in this learning method. Specifically, geography is one of the sciences best positioned to address these SDGs, and sustainability issues in general $[58,59]$. In any case, it is the skill and motivation of the teaching staff that will help drive and sustain this curriculum.

\section{Conclusions}

A resource and a working method have been offered to future secondary school teachers, who from different specialties, mainly geography, history, art, economics and journalism, follow the Master's degree in Teacher Training at the Complutense University of Madrid in the specialty of Geography and History. This study has detailed an outdoor activity, which many of them have undertaken, which is based in medieval Madrid and can 
be extrapolated to any historical center. Students' sensitivity towards cultural heritage and coexistence with the resident population can foster a deeper understanding of this tangible and intangible historical and cultural heritage. Additionally, teaching competencies have been promoted so that teachers in training can observe how to organize educational activities that link in with the goals proposed by SDG 4: Work to achieve "quality education" and "ensure that all learners acquire the knowledge and skills needed to promote sustainable development, including, among others, through education for sustainable development and sustainable lifestyles, human rights, gender equality, promotion of a culture of peace and non-violence, global citizenship and appreciation of cultural diversity and of culture's contribution to sustainable development" (goal 4.7). Inductive and experiential, functional, permanent and meaningful learning is facilitated, so that students approach heritage in a different and fun way, which they are able to transmit to their own students, taking the SDGs as a reference. Thus, it can be considered a transformative teaching method that integrates the key competences for sustainability detailed by UNESCO and the education expert Professor Murga-Menoyo [68-70] (who also works in critical analysis, systemic reflection, collaborative decision making and responsibility towards present and future generations).

The objectives that were established at the outset of this study have been met and the students have considered the proposed orientation game as a dynamic and fun learning activity that is very suitable for implementation in secondary schools. In addition, it has been shown how learning outside the classroom reinforces what is learned within, and how the integration of mobile technologies can be carried out in a natural, logical, applied and shared way, which promotes effective and meaningful learning.

The data obtained from the teacher target group has been essential in assessing the transformation experienced by the students/future teachers, in relation to how they approach their professional future, their teaching skills and, specifically, the heritage culture that goal 11.4 fosters.

The future teachers in this study have experienced the orientation game, and have learned to organize a didactic activity, with its pros and cons, to promote the appreciation of heritage in students and, in the process, made it possible to extrapolate it to other territorial and patrimonial realities.

Author Contributions: Conceptualization, M.-L.G.-R., F.-J.M.-Y. and M.-L.d.L.-T.; methodology, M.L.G.-R., and M.-L.d.L.-T.; formal analysis, M.-L.G.-R., F.-J.M.-Y. and M.-L.d.L.-T.; writing-review and editing, M.-L.G.-R., F.-J.M.-Y. and M.-L.d.L.-T. All authors have read and agreed to the published version of the manuscript.

Funding: This research received no external funding.

Institutional Review Board Statement: Not applicable. The study did not require ethical approval.

Informed Consent Statement: Informed consent was obtained from all subjects involved in the study.

Data Availability Statement: The data presented in this study are available on request from the corresponding author.

Acknowledgments: «La alfabetización ecosocial: un elemento central en los procesos de sostenibilización curricular para el logro de la Agenda 2030 (ODS) en la formación inicial del profesorado (PRAD-ODS)» «Ecosocial literacy: a central element in the processes of curricular sustainability for the achievement of the 2030 Agenda (SDG) in initial teacher training» (RTI2018-095746-B-I00), (Ministry for Science, Innovation and Universities). Innovative Pedagogies for Teaching with Geoinformation (GI-Pedagogy) (2019-1-UK01-KA203-061576) KA2 - Cooperation for Innovation and the Exchange of Good Practices. KA203-Strategic Partnerships for higher education (European Commission).

Conflicts of Interest: The authors declare no conflict of interest. 
Appendix A

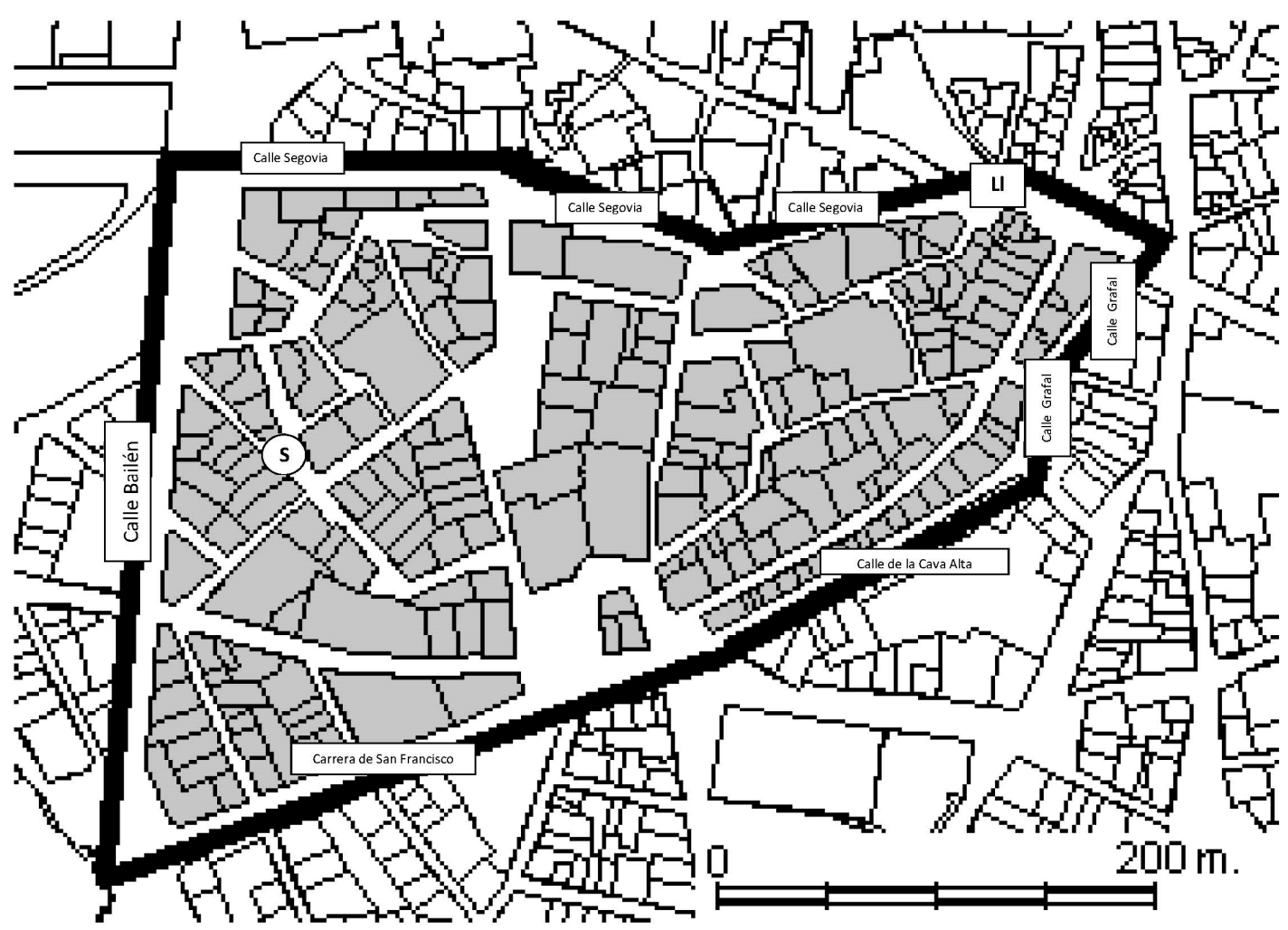

Figure A1. Blank map for the orientation game. S, is the starting point (Plaza del Granado or Granado square) and Ll is the end point (Puerta Cerrada or Closing Gate).

\section{Appendix B}

Old Madrid: looking for 'treasures' and the 'selfie challenge'.

We are going to learn about treasures in the oldest part of Madrid.

You don't need to go outside these boundaries (add the names of these streets on the map):

- North: Segovia Street

- West: Bailén Street

- South: Carrera de San Francisco

- SE and East: Cava Alta and Grafal Streets

You should keep inside this defined area the whole time. There will be staff nearby in case you need to contact someone.

Main steps:

- $\quad$ Departure or starting point (S): Plaza del Granado (square)

For one hour you must try to: locate the places by the street names, coordinates and a landmark on the map with its corresponding code name; answer the questions; and photograph the places including at least two members of the group in the photograph ('selfie').

To avoid getting lost, it is important that you write on this map the names of the streets that define the area.

Be respectful with the cars, the place and the people! Keep together as a group at all times.

- Your research points:

1. Casa del Pastor (House of the Shepherd). Photograph it with at least two members of the group. Answer these questions: Name of the Street it is located on: 
Coordinates: Locate it on the map as CPast What is left of the old building? Why is it called Casa del Pastor?

2. Iglesia de San Pedro (San Pedro Church). Photograph it with at least two members of the group. Answer these questions: Name of the Street: Coordinates: Locate it on the map as ISPedro

- Why is this church so important?

3. Casa-Museo de San Isidro (Museum of San Isidro, his home). Photograph it with at least two members of the group. Answer these questions: Name of the Street: Coordinates: Locate it on the map as CMSI Who was San Isidro? What was his wife's name?

4. Capilla del Obispo (Chapel of the Bishop). Photograph it with at least two members of the group. Answer these questions: Name of the square: Coordinates: Locate it on the map as CBishop. What is the artistic style of the building?

5. Colegio de San Ildefonso (School of San Ildefonso). Photograph it with at least two members of the group. Answer these questions: Name of the Street: Coordinates: Locate it on the map as CSIld Why is this school so famous?

6. Jardines del Palacio de Anglona (Gardens of the Palace of Anglona). Photograph it with at least two members of the group. Answer these questions: Names of the square and the street: Coordinates: Locate it on the map as JPAng

Currently the building to which these gardens belong is no longer a palace. What is its current use?

- $\quad$ Arrival point (Ll): Puerta Cerrada square

The team who completes all the challenges correctly first will win a prize. It is necessary to arrive with the locations marked on the map, all the questions correctly answered, and the selfies on your telephone.

See you at Puerta Cerrada square in one hour!!!

Names of the group members: ............

\section{Appendix C}

The teacher's version to carry out the activity: Practical issues \& main characteristics, location and an image of each treasure (Tables A1 and A2 and Figure A2).

- Management of the game

Each group should comprise three students. The students are given one set of instructions and a map for each group.

Upon departure, the students are given a number on a set of photocopies. The game finishes at Puerta Cerrada in one hour. Teachers correct in the following way:

Marks: 30 points maximum, if all the items are correct and have been completed in no more or less than one hour.

Each 'treasure' is worth up to five points: photo/selfie (1), answers (1), street (1), coordinates (1) and landmark on the map (1).

There are three prizes, the third prize is given first, the second second, and the first prize is given last. In order to make this more interesting, students are present while the teachers correct the questionnaire.

- Selfie challenge—game solutions Departure place: Plaza del Granado (S) Arrival place: Puerta Cerrada (Ll) Difficulty of route: Altitude: between 618 and $646 \mathrm{~m}$ 
Table A1. The six geolocated "treasures".

\begin{tabular}{ccccc}
\hline Treasure & \multicolumn{2}{c}{ Degrees, Minutes and Seconds } & \multicolumn{2}{c}{ Decimal Degrees } \\
\hline Casa del Pastor & $40^{\circ} 24^{\prime} 49.09^{\prime \prime} \mathrm{N}$ & $3^{\circ} 42^{\prime} 47.80^{\prime \prime} \mathrm{W}$ & 40.413649 & -3.713235 \\
Iglesia de San Pedro & $40^{\circ} 24^{\prime} 47.89^{\prime \prime} \mathrm{N}$ & $3^{\circ} 42^{\prime} 37.67^{\prime \prime} \mathrm{W}$ & 40.413298 & -3.710366 \\
Casa-Museo de San & $40^{\circ} 24^{\prime} 43.44^{\prime \prime} \mathrm{N}$ & $3^{\circ} 42^{\prime} 39.05^{\prime \prime} \mathrm{W}$ & 40.412084 & -3.710885 \\
$\quad$ Isidro & $40^{\circ} 24^{\prime} 45.04^{\prime \prime} \mathrm{N}$ & $3^{\circ} 42^{\prime} 41.76^{\prime \prime} \mathrm{W}$ & 40.412457 & -3.711534 \\
Capilla del Obispo & $40^{\circ} 24^{\prime} 45.97^{\prime \prime} \mathrm{N}$ & $3^{\circ} 42^{\prime} 43.92^{\prime \prime} \mathrm{W}$ & 40.412784 & -3.712177 \\
$\begin{array}{c}\text { Colegio San Ildefonso } \\
\text { Jardines palacio }\end{array}$ & $40^{\circ} 24^{\prime} 48.58^{\prime \prime} \mathrm{N}$ & $3^{\circ} 42^{\prime} 41.04^{\prime \prime} \mathrm{W}$ & 40.413429 & -3.711422 \\
$\quad$ Anglona & & & & \\
\hline
\end{tabular}

Table A2. The six treasures characteristics.

\begin{tabular}{cccc}
\hline Treasures & Street/Square & Answers to Questions \\
\hline 1. Casa del Pastor (CPast) & (c) Segovia and Caños Viejos Street & $\begin{array}{l}\text { On the building the old shield remains (s.XVII) } \\
\text { representing the symbols of the city: the bear } \\
\text { and the strawberry tree (madrono).It is called } \\
\text { the Casa del Pastor because it was inherited by } \\
\text { a shepherd. }\end{array}$
\end{tabular}

2. Iglesia de San Pedro (el Viejo) (ISPedro)

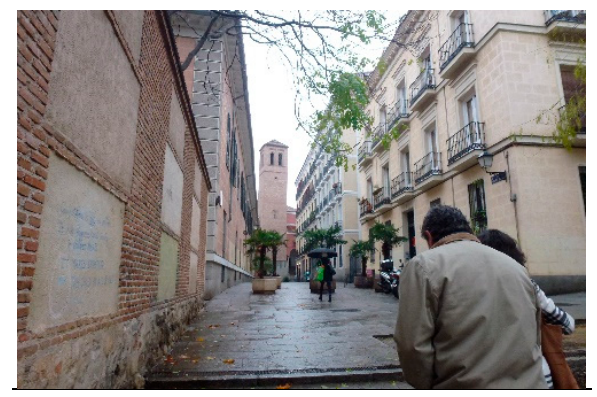

San Pedro church is one of the oldest (s.XIII) mentioned in the Law of Madrid of 1202, as one of its parishes. Its Moorish tower dates back to the fourteenth century, it is built of brick, and the small windows are enhanced with horseshoe arches.

3. Casa-Museo de San Isidro (CMSI)

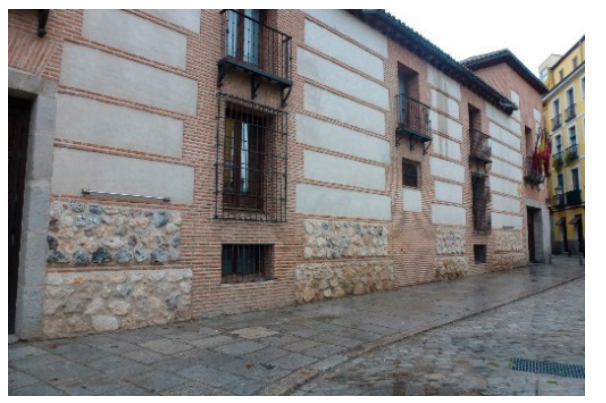

Pza. San Andrés square

Saint Isidro was a farmer at the service of the wealthy Vargas family. His wife was called María de la Cabeza and she also became a saint. They are the holy patrons of Madrid. 
Table A2. Cont.

\begin{tabular}{ccc}
\hline Treasures & Street/Square & Answers to Questions \\
\hline 4. Capilla del Obispo (Cbishop) & Pza. de la Paja square $\quad$ The style of the building is gothic-plateresque.
\end{tabular}

\section{Colegio San Ildefonso (CSIld)}

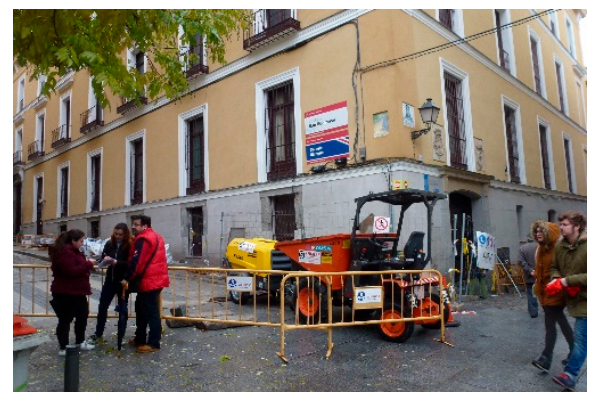

(c) Redondilla and del Granado Street
It is a European bilingual school that is also famous for the lottery (which is very popular at Christmas).

6. Jardines palacio Anglona (JPAng)

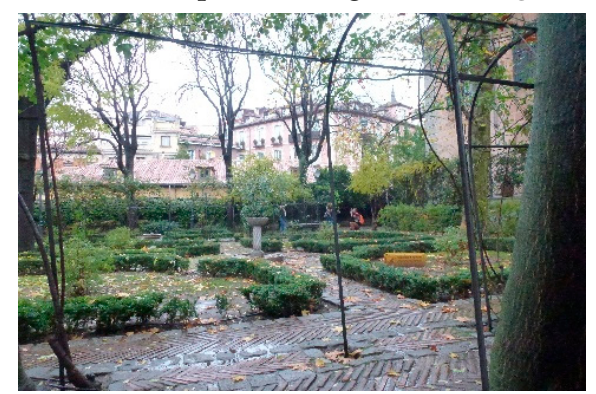

Pza. De la Paja square and Príncipe de Anglona
The palace has been replaced by a new apartment building 


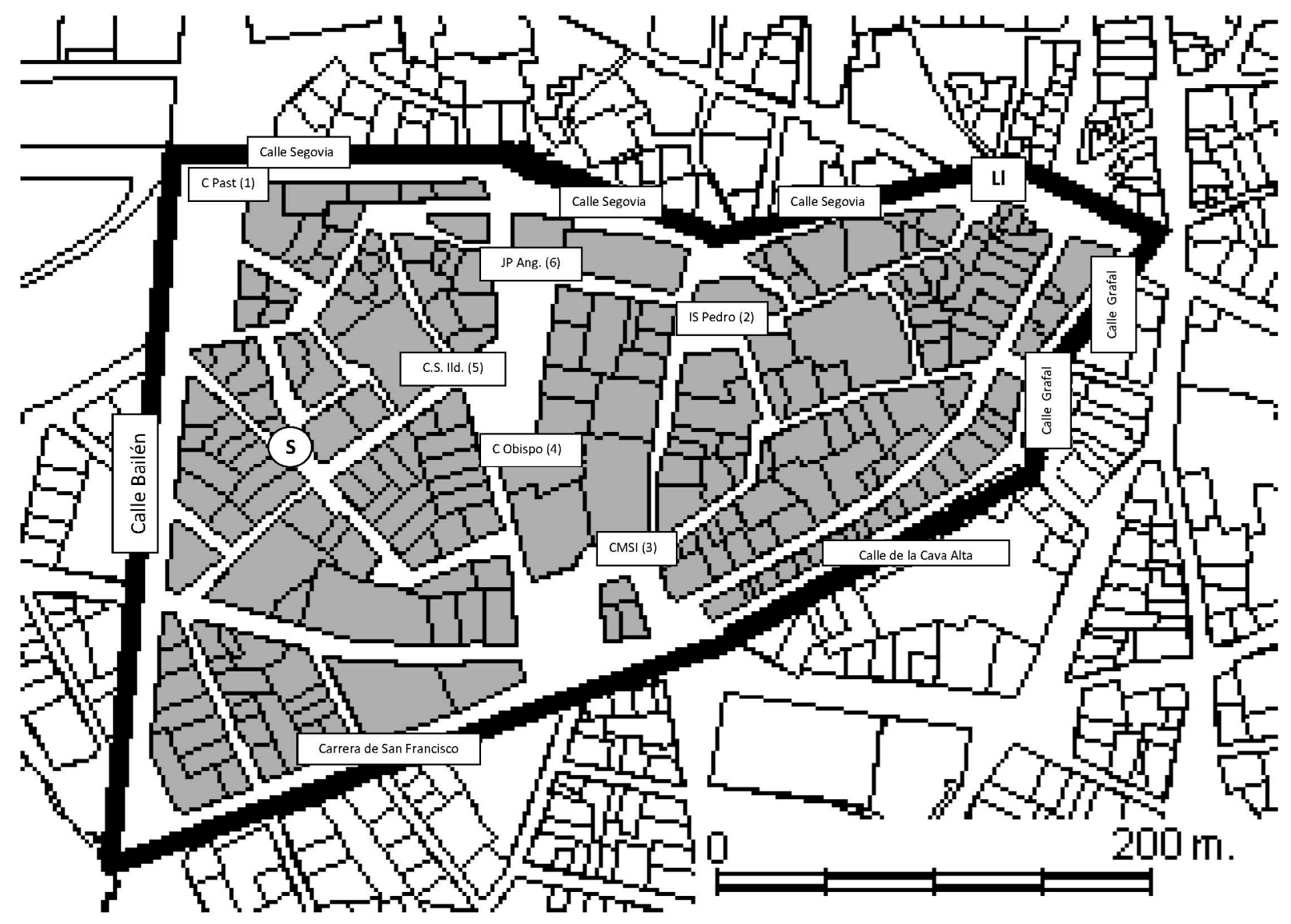

Figure A2. Location of treasures on the map.

\section{References}

1. UN. Transforming Our World: The 2030 Agenda for Sustainable Development; United Nations: New York, NY, USA, 2015. Available online: https://sustainabledevelopment.un.org/content/documents/21252030\%20Agenda\%20for\%20Sustainable\%20 Development\%20web.pdf (accessed on 4 January 2021).

2. Raszkowski, A.; Bartniczak, B. On the Road to Sustainability: Implementation of the 2030 Agenda Sustainable Development Goals (SDG) in Poland. Sustainability 2019, 11, 366. [CrossRef]

3. Koch, F.; Krellenberg, K. How to Contextualize SDG 11? Looking at Indicators for Sustainable Urban Development in Germany. ISPRS Int. J. Geo-Inf. 2018, 7, 464. [CrossRef]

4. Weybrecht, G. From challenge to opportunity-Management education's crucial role in sustainability and the Sustainable Development Goals-An overview and framework. Int. J. Manag. Educ. 2017, 15, 84-92. [CrossRef]

5. Quiroz-Niño, C.; Murga-Menoyo, M.Á. Social and Solidarity Economy, Sustainable Development Goals, and Community Development: The Mission of Adult Education \& Training. Sustainability 2017, 9, 2164. [CrossRef]

6. Murga-Menoyo, M.Á.; Correia, F.; Espinosa, Á. Transition towards sustainability in Hull University Business School: A study of curricular sustainability in the teaching processes. In Handbook of Sustainability Science and Research; Springer: Cham, Switzerland, 2018; pp. 783-802.

7. Borderías Uribeondo, M. Reflexiones al finalizar la “Década de las Naciones Unidas de Educación para el Desarrollo Sostenible 2005-2014": Referencias ambientales en los Grados de la UNED y aportación de la Geografía a la EDS. Espac. Tiempo Forma Ser. VI Geogr. 2015, 6-7, 19-31. [CrossRef]

8. Fernández-Valencia, A. La ciudad, espacio para el aprendizaje de ciencias sociales y valoración del patrimonio heredado. In El Patrimonio y la Didáctica de las Ciencias Sociales; Ballesteros Arranz, E., Fernández, C.F., Molina Ruiz, J.A., Moreno Benito, P., Eds.; Universidad de Castilla-La Mancha i Asociación Universitaria de Profesores de Didáctica de las Ciencias Sociales: Cuenca, Spain, 2003; pp. 387-398.

9. Aragoneses, J.; Mínguez, C. The Geographical Systems Information: Tools for the Effective Management of the Cultural Heritage from Natural Disasters. In Geospatial Challenges in the 21st Century; Springer: Cham, Switzerland, 2019; pp. 11-37. [CrossRef]

10. Estepa, J. La Educación Patrimonial en la Escuela y el Museo: Investigación y Experiencias; Universidad de Huelva: Huelva, Spain, 2013.

11. Fontal, O.; Ibáñez, A. Estrategias e instrumentos para la educación patrimonial en España. Educ. Siglo XXI 2015, 33, 15-32. [CrossRef] 
12. Fontal, O.; Ceballos, S.G.; Arias, B.; Arias, V.B. Evaluación de la calidad de programas de educación patrimonial: Construcción y calibración de la escala Q-Edutage. Rev. Psicodidact. 2019, 24, 31-38. [CrossRef]

13. MECD Plan Nacional de Educación y Patrimonio. 2021. Available online: http://www.culturaydeporte.gob.es/planesnacionales/planes-nacionales/educacion-y-patrimonio.html (accessed on 4 January 2021).

14. Observatorio de Educación Patrimonial en España. Available online: http:/ / www.oepe.es/ (accessed on 4 January 2021).

15. Fontal, O.; Martínez, M. The Heritage and Education Research Network: Place Value on Cultural Heritage in Europe. In Handbook of Research on Citizenship and Heritage Education; IGI Global: Hershey, PA, USA, 2020; pp. 173-196.

16. Red Internacional de Educación Patrimonial. Available online: http:/ / www.riep-inhe.com/ (accessed on 4 January 2021).

17. Jagielska-Burduk, A.; Stec, P. Council of Europe Cultural Heritage and Education Policy: Preserving Identity and Searching for a Common Core? Rev. Electrón. Interuniv. Form. Profr. 2019, 22, 1-12. [CrossRef]

18. Fontal, O.; Ibañez-Etxeberria, A. La investigación en Educación Patrimonial. Evolución y estado actual a través del análisis de indicadores de alto impacto Research on Heritage Education. Evolution and Current State Through analysis of High Impact Indicators. Rev. Educ. 2017, 375, 184-214.

19. Priestnall, G. Landscape Visualization in Fieldwork. J. Geogr. High. Educ. 2009, 33, S104-S112. [CrossRef]

20. Martín, M.J.; Cuenca, J.M. La Enseñanza y el Aprendizaje del Patrimonio en los Museos: La Perspectiva de los Gestores. Rev. Psicodidáct. 2011, 16, 99-122. Available online: https://ojs.ehu.eus/index.php/psicodidactica/article/view/1114/792 (accessed on 4 January 2021).

21. Gómez Ruiz, M.L. El Tratamiento de los Procedimientos en la Geografía del Bachillerato: Nuevas Propuestas de Metodología Activa a Partir de la Investigación Empírica; Colección Digital de Tesis de la Universidad Complutense de Madrid: Madrid, Spain, 2010. Available online: http:/ / eprints.ucm.es/ (accessed on 4 January 2021).

22. Lleida, M. El patrimonio Arquitectónico, una Fuente para la Enseñanza de la Historia y de las Ciencias Sociales. Enseñ. Cienc. Soc. 2010, 9, 41-50. Available online: https://www.raco.cat/index.php/EnsenanzaCS/article/view/191357 (accessed on 4 January 2021).

23. Gómez Ruiz, M.L. Los Cambios en el Medio Urbano Como Instrumento Didáctico Para Trabajar la Percepción Espacial. In Aportaciones de la Geografía en el Aprendizaje a lo Largo de la Vida; Delgado, J.J., Lázaro, M.L., Marrón, M.J., Eds.; Grupo de Didáctica de la Geografía de la Asociación de Geógrafos Españoles: Sevilla, Spain, 2011; pp. 488-502. Available online: http:/ / didacticageografia.age-geografia.es / / docs/Publicaciones/2011_Aportaciones_Geografia.pdf (accessed on 4 January 2021).

24. López, C.T. La Enseñanza del Patrimonio a Partir del Entorno Próximo a los Centros Educativos. Análisis Documental. Clío 2013, 39, 1-58. Available online: http:/ / clio.rediris.es/n39/articulos/lopezarroyo.pdf (accessed on 4 January 2021).

25. Segrelles, L.M. La Tècnica de L'itinerari Didàctic i la Seua Aplicació al Patrimoni Històric de la Vall D'albaida; Curs Impartit al Centre de Formació de Professorat d'Ontinyent; Centre de Formació de Professorat d'Ontinyent: Ontinvent, Spain, 1996.

26. Abril Gallego, A.M.; Gallego, A.M.A.; Quesada, M.C.; Rodríguez, A.C.; Bedmar, M.d.C.D.; Carmona, M.D.G.; Martínez, M.V.M.; García, F.J.M.; Rodríguez, M.P.; Balboa, B.R.; et al. El agua: Itinerarios didácticos por el patrimonio histórico-artístico y espacios naturales de la zona de Sierra Mágina (Jaén). In Didáctica de las Ciencias Sociales, Currículo Escolar y Formación del Profesorado. La didáctica de las Ciencias Sociales en los Nuevos Planes de Estudio; Ávila Ruiz, R.M., Alcázar Cruz Rodríguez, M., Díez Bedmar, M.d.C., Eds.; Servicio de Publicaciones de la Universidad de Jaén: Jaén, Spain, 2003; pp. 703-704.

27. Cruz, L.A. Itinerario Geodidáctico a la Laguna de Peñalara (Madrid). In Aportaciones de la Geografía para Aprender a lo Largo de la Vida; Delgado, J.J., Lázaro, M.L., Marrón, M.J., Eds.; Universidad de Málaga: Málaga, Spain, 2011; pp. $433-446$.

28. Gómez Ruiz, M.L.; Lázaro, M.L.; González, M.J. Impulsar las Competencias Espaciales y Digitales a Través de un Viaje Virtual por Getafe. In La Educación Geográfica Digital; De Miguel, R., De Lázaro, M.L., Marrón, M.J., Eds.; Grupo de Didáctica de la Geografía de la Asociación de Geógrafos Españoles, Universidad de Zaragoza: Zaragoza, Spain, 2012; pp. 471-484. Available online: http:/ / didacticageografia.age-geografia.es/docs/Publicaciones/2012_Educacion_Digital.pdf (accessed on 4 January 2021).

29. Crespo, J.M. Un Itinerario Didáctico Para la Interpretación de los Elementos Físicos de los Paisajes de la Sierra de Guadarrama. Didáct. Geogr. 2013, 13, 15-34. Available online: https://didacticageografica.age-geografia.es/index.php/didacticageografica/ article/view/94 (accessed on 4 January 2021).

30. Alcolea Moratilla, M.A.; Buzo Sánchez, I.; Crespo Castellanos, J.M.; Cruz Naïmi, L.A.; De Lázaro y Torres, M.L.; De Miguel González, R.; Delgado Peña, J.J.; Gómez Ruiz, M.L.; González Castañé, M.; González González, M.J.; et al. Aprender Geografía de España con la Web 2.0; Editorial Universidad Complutense de Madrid, Vicerrectorado de Evaluación de la Calidad de la Universidad Complutense de Madrid: Madrid, Spain, 2014. Available online: http:/ / eprints.ucm.es/27995/ (accessed on 4 January 2021).

31. Fuertes, C.; Cantó, J. La tècnica de l'itinerari didàctic en la formació inicial del professorat: Reconstrucció d'una experiencia. @tic. Rev. D'innov. Educ. 2015, 14, 23-30. [CrossRef]

32. Comănescu, L.; Nedelea, A.; Stănoiu, G. Geomorphosites and geotourism in Bucharest city center (Romania). Quaest. Geogr. 2017, 36, 51-61. [CrossRef]

33. Crespo Castellanos, J.; Gómez Ruiz, M.; Cruz Naïmi, L. Una aproximación a los Parques Nacionales y sus paisajes a través de itinerarios didácticos. Espac. Tiempo Forma Ser. VI Geogr. 2018, 11, 121-140. [CrossRef] 
34. Mínguez García, M.C. El Paisaje Como Objeto de Estudio de la Geografía. Un Itinerario Didáctico en el Marco de la Semana de la Ciencia de la Comunidad de Madrid. Didáct. Geogr. 2010, 11, 37-62. Available online: https:/ / didacticageografica.age-geografia. es/index.php/didacticageografica/article/view/40 (accessed on 4 January 2021).

35. Mínguez García, M. La enseñanza del turismo: Diseño de rutas urbanas usando los GIS Story Maps. Investig. Geogr. 2020. [CrossRef]

36. García, A. Didáctica del Museo; Ediciones de la Torre: Madrid, Spain, 1998.

37. Asensio, M.; Pol, E. Nuevos Escenarios en Educación. Aprendizaje Informal sobre el Patrimonio, los Museos y la Ciudad; Aique: Buenos Aire, Argentina, 2002.

38. García, P.; Martín, P. Museos arqueológicos de Gijón. El patrimonio arqueológico como recurso didáctico. Íber. Didáct. Cienc. Soc. Geogr. Hist. 2009, 59, 53-66.

39. Fontal, O.; Ibáñez-Etxeberria, A.; Martín, L. Reflexionar Desde las Experiencias. Una Visión Complementaria Entre España, Francia y Brasil. Actas del II Congreso Internacional de Educación Patrimonial; IPCE/OEPE: Madrid, Spain, 2014.

40. Delgado, J.J.; Fernández, J.C. Spatial skills for the improvement of the quality of life of seniors. Experiences in Málaga and Antequera (Spain). In Geographic and Geolocation Competences for People in Later Life; Delgado, J.J., Ed.; Outdoor ICT Grundtvig Partnership Funded by EACEA (EU Lifelong Learning Programme): University of Málaga: Málaga, Spain, 2013; pp. 80-89. Available online: http:/ / www.e-seniors.asso.fr/OutDoorIctHandbook.pdf (accessed on 4 January 2021).

41. Colton Flynn, K.; Popp, J. An Experiential-Based Learning Method Aiming to Improve Spatial Awareness Utilizing GPS, Geocaching, and Geo-Selfies. Geogr. Teach. 2016, 13, 61-71. [CrossRef]

42. Ibáñez, A.; Vicent, N.; Asensio, M. Aprendizaje Informal, Patrimonio y Dispositivos Móviles. Evaluación de una Experiencia en Educación Secundaria. Didáct. Cienc. Exp. Soc. 2012, 26, 3-18. Available online: https://ojs.uv.es/index.php/dces/article/view / $1937 / 1441$ (accessed on 4 January 2021).

43. Woodcock, B.; Middleton, A.; Nortcliffe, A. Considering the Smartphone Learner: An Investigation into Student Interest in the Use of Personal Technology to Enhance Their Learning. Stud. Engagem. Exp. J. 2012, 1, 1-15. Available online: http: //shura.shu.ac.uk/5256/1/WoodcockSEEJ.pdf (accessed on 20 January 2021).

44. Martín Dorta, N.N. Análisis del Uso de Dispositivos Móviles en el Desarrollo de Estrategias de Mejora de las Habilidades Espaciales. Ph.D. Thesis, Universitat Politècnica de València, València, Spain, 2009. [CrossRef]

45. De Lázaro, M.L.; Alcolea, M.A.; Palacios, M.T. Dispositivos Móviles: Una Herramienta Para el Aprendizaje en Geografía y en los Trabajos de Campo. In Actas del II Congreso Internacional sobre Aprendizaje, Innovación y Competitividad; Fidalgo, A., Sein-Echaluce, M.L., Eds.; Universidad Politécnica de Madrid: Madrid, Spain, 2013; pp. 685-690. Available online: http: //138.4.83.137/dmami/documentos/liti/ACTAS_CINAIC_2013.pdf (accessed on 4 January 2021).

46. France, D.; Whalley, B.W.; Mauchline, A. From the International Desk: Using Mobile Devices to Enhance Undergraduate Field Research. Council on Undergraduate Research. CUR Q. 2013, 34, 38-42. Available online: http:/ /scholar.google.co.uk/scholar? oi=bibs\&hl=en\&cluster=2884559852876917386\&btnI=Lucky (accessed on 4 January 2021).

47. France, D.; Whalley, W.B.; Mauchline, A.; Powell, V.; Welsh, K.; Lerczak, A.; Park, J.; Bednarz, R. Enhancing Fieldwork Learning Using Mobile Technologies; Springer Briefs in Ecology; Springer: Cham, Switzerland; New York, NY, USA, 2015. [CrossRef]

48. Sebastian, M.; De Miguel, R. Geographical Education 2020: Iberpix and Collector for ArcGIS as Teaching Resources for Spatial Learning. Didáct. Geogr. 2017, 18, 231-246. Available online: https://didacticageografica.age-geografia.es/index.php/ didacticageografica/article/view/391 (accessed on 4 January 2021).

49. Sebastián-López, M.; de Miguel González, R. Mobile Learning for Sustainable Development and Environmental Teacher Education. Sustainability 2020, 12, 9757. [CrossRef]

50. Vigotsky, L.S. Pensamiento y Lenguaje; La Pléyade: Buenos Aires, Argentina, 1977.

51. Novak, J.D. Aprendiendo a Aprender; Martínez Roca: Barcelona, Spain, 1988.

52. Elosúa de Juan, M.R. El aprendizaje significativo desde un enfoque social. Rev. Psicol. Univ. Tarracon. 1992, 14, 7-16.

53. Bailey, P. Didáctica de la Geografía; Cincel: Madrid, Spain, 1987.

54. Liceras, A.; Romero, G. Didáctica de las Ciencias Sociales; Pirámide: Madrid, Spain, 2016.

55. Centro Nacional de Información Geográfica (CNIG). App Mapas de España. Available online: https://play.google.com/store/ apps / details?id=com.orux.oruxmapsIGN\&hl=es (accessed on 4 January 2021).

56. Summers, M.; Childs, A.; Corney, G. Education for sustainable development in initial teacher training: Issues for interdisciplinary collaboration. Environ. Educ. Res. 2005, 11, 623-647. [CrossRef]

57. Annan-Diab, F.; Molinari, C. Interdisciplinarity: Practical approach to advancing education for sustainability and for the Sustainable Development Goals. Int. J. Manag. Educ. 2017, 15, 73-83. [CrossRef]

58. Asmara, C.H.; Anwar, K.; Muhammad, R.N. EFL Learners' Perception toward an Outdoor Learning Program. International J. Educ. Lit. Stud. 2016, 4, 74-81. Available online: https://www.journals.aiac.org.au/index.php/IJELS/article/view/2430 (accessed on 14 January 2021).

59. Alkhafaji, A.; Fallahkhair, S.; Haig, E. A theoretical framework for designing smart and ubiquitous learning environments for outdoor cultural heritage. J. Cult. Herit. 2020, 46, 244-258. [CrossRef]

60. Cook, V.A.; Phillips, D.; Holden, J. Geography fieldwork in a 'risk society'. Area 2006, 38, 413-420. [CrossRef]

61. Fuller, I.C. Taking students outdoors to learn in high places. Area 2012, 44, 7-13. [CrossRef] 
62. Dillon, J.; Rickinson, M.; Teamey, K.; Morris, M.; Choi, M.Y.; Sanders, D.; Benefield, P. The Value of Outdoor Learning: Evidence from Research in the UK and Elsewhere. Sch. Sci. Rev. 2006, 87, 107. Available online: https:/ /www.univie.ac.at/freilanddidaktik/ literatur/Dillon_School\%20Sc.\%20Rev._2006_The\%20value\%20of\%20outdoor\%20learning.pdf (accessed on 14 January 2021).

63. Morrissey, J.; Clavin, A.; Reilly, K. Field-based learning: The challenge of practising participatory knowledge. J. Geogr. High. Educ. 2013, 37, 619-627. [CrossRef]

64. Mirrahimi, S.; Tawil, N.M.; Abdullah, N.A.G.; Surat, M.; Usman, I.M.S. Developing Conducive Sustainable Outdoor Learning: The Impact of Natural Environment on Learning, Social and Emotional Intelligence. Procedia Eng. 2011, 20, 389-396. Available online: https:/ / core.ac.uk/download/pdf/82790789.pdf (accessed on 14 January 2021). [CrossRef]

65. Madariaga-Orbea, J.M.; Gillate, I.; Ibañez-Etxeberria, A.; Molero, B. Heritage education in informal contexts. Motivation and self-concept/Educación patrimonial en contextos informales. Motivación y autoconcepto. Cult. Educ. 2018, 30, 584-599. [CrossRef]

66. Kohen-Vacs, D.; Ronen, M.; Cohen, S. Mobile Treasure Hunt Games for Outdoor Learning. Bull. IEEE Tech. Comm. Learn. Technol. 2012, 14, 24-26. Available online: http:/ / tc.computer.org/tclt/wp-content/uploads/sites/5/2018/01/Kohen.pdf (accessed on 14 January 2021).

67. Tan, Y.S.M.; Atencio, M. Unpacking a place-based approach-“What lies beyond?” Insights drawn from teachers' perceptions of Outdoor Education. Teach. Teach. Educ. 2016, 56, 25-34. [CrossRef]

68. Murga-Menoyo, M.A. Competencias para el desarrollo sostenible: Las capacidades, actitudes y valores meta de la educación en el marco de la agenda global post-2015. Foro Educ. 2015, 13, 55-83. [CrossRef]

69. Murga-Menoyo, M.A. El camino hacia los ODS: Conformar una ciudadanía planetaria mediante la educación. Comillas J. Int. Relat. 2020, 19, 1-11. [CrossRef]

70. Tomás, M.P.; Murga-Menoyo, M.A. El marco curricular de la Educación Secundaria Obligatoria: Posibilidades para la formación de competencias en sostenibilidad. Rev. Int. Comun. Desarro. 2020, 3, 90-109. [CrossRef] 